\title{
Analysis of Various Service Discovery Protocols for Infrastructure-less Networks
}

\author{
S. Thangam \\ Research Scholar, \\ Anna University \\ Trichy, Tamilnadu, India
}

\author{
Dr.E.Kirubhakaran \\ Sr DGM (out sourcing), BHEL, \\ Trichy, Tamilnadu, India
}

\begin{abstract}
Globe is looking forward to new technologies that allow them to communicate anytime, anywhere, and using any communication device. This is possible by infrastructure-less wireless networks in which nodes can communicate directly to each other (without a central coordinator) and can relay data to each other in a selforganizing fashion.. Past researches mostly concentrated on problems on low level technologies necessary for formation of adhoc and peer-peer. But the basic role is to allow mobile users to exchange data and use each other services. Many researches has been done on lower level such as routing and resource scarcity but its important to identify higher level service discovery to implement MANET for civilian applications. So we insist on necessity of higher level service discovery that is required for MANET and various existing protocols.
\end{abstract}

Keywords: adhoc, peer-peer, infra structureless, peer-peer, services

\section{INTRODUCTION}

Service discovery is a processing logic that is precise, self-reliant and allows network entities to publicize their services, queries about services provided by other entities, select apposite matched service and invoke services.[1][2][3]. They do not depend on the context or state of other services. In Mobile ad hoc networks disparate nodes offering diverse services may enter and leave the network at any time. Efficient and timely service discovery is a prerequisite for good exploitation of shared resources on the network. Challenges of service discovery in MANET are mobility, limited power supply, computational resources, memory and the server and client frequently join and leave the network. The resources that need to be shared or searched are packaged as services. Services can be those offered by devices or simply software services that are device independent. Scenarios where the services of MANET are availed [10] are

- Crisis relief scenario

- In an Airport lounge

- Locating nearby café or important place of visit

- Business

- $\quad$ Sharing games

\section{SERVICE DISCOVERY PROTOCOLS}

Basic connectivity problem alone is not sufficient for adaptation in MANET.Basic role is to allow mobile users to exchange their data and services. So there is need for architecture, mechanism and protocol for service discovery. Function of SDP [4]

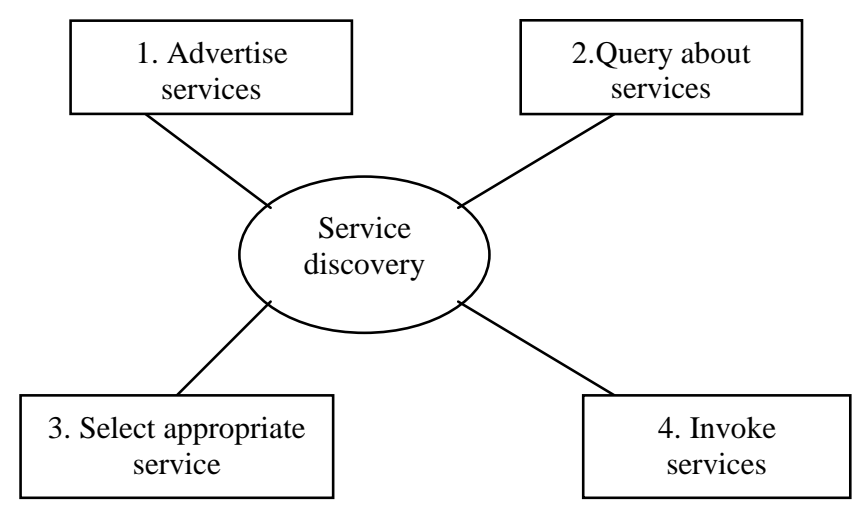

Figure: 1

Existing service discovery protocols for mobile ad-hoc networks based on whether a directory exists or not as directory-less architecture and directory-based architecture. A directory is an entity that stores information about services available in the network so as to enable service discovery and invocation. The directory-based architecture can be divided into two categories: centralized directory architecture and distributed directory architecture. The centralized directory architecture relies on one or a few centralized directories that store the descriptions of all services available in the network. On the other hand, in the distributed directory architecture,

Directories are further disseminated and deployed dynamically. The distributed directory architecture is subdivided, depending on whether directories reside on mobile ad hoc networks or on infrastructure-based networks, into two categories: infrastructureless distributed directory architecture and infrastructure-based distributed directory architecture. Independent of the chosen service discovery architecture, service information can be gathered either in a reactive, proactive or hybrid way. Using a reactive mode, a service requester node creates a query ondemand whenever a certain service is desired The query is then sent to the network either using unicast, broadcast or multicast depending on the service discovery architecture.
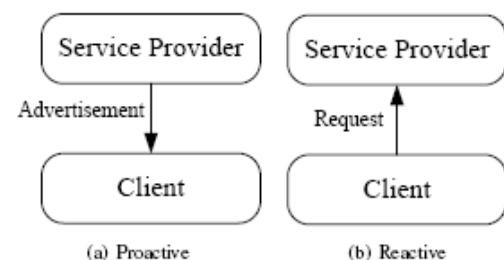

Figure:2

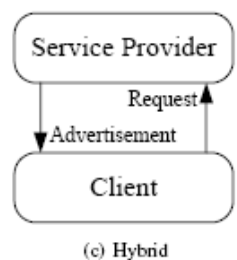

(c) Hybrid

A proactive mode implies that service providers proactively distributes their available services

The distribution is performed either directly to potential service clients or to service directories. Obviously, this approach yields more traffic than the reactive mode. On the other hand, the initial service discovery delay is reduced.A hybrid discovery 
mode supports both reactive requests and proactive service advertisements This approach must then support that the service information may be distributed in several ways depending on topology. Some nodes may know all service information, while some nodes have no information at all and must rely on creating service requests.

\section{VARIOUS SERVICE DISCOVERY APPROACHES DEVELOPED AND ADOPTED BY INDUSTRY}

\subsection{SLP}

SLP is a protocol that was developed by the IEFT for services discovery.Commercial products like Hewlett Packard,IBM has embedded it in its commercial products. It addresses service discovery and not invocation.[2, 3, 7] supports operations of services discovery with For the discovery of services it uses the methodologies active/pull and passive/push.

[6] There are three agents in SLP: User Agent (UA), Service Agent (SA), and Directory Agent (DA). UA is a software entity that sends service discovery requests on behalf of a user application. SA is an entity that advertises service on behalf of a service. As a centralized service information repository, DA caches advertisements from SAs and, afterwards, responds to requests from UAs.

\subsection{Jini [11]}

The system is a service discovery architecture specifying how service discovery and invocation are performed among java enabled devices. Architectural sub systems are:

$$
\begin{aligned}
& \text { Clients } \\
& \text { Server } \\
& \text { Lookup Servers }
\end{aligned}
$$

Service providers registers their service with lookup server by sending service objects along with attributes

\subsection{UPnP[12]}

The protocol UpnP (Universal Plug and Play) is an open protocol that was developed from a forum of companies which leads the Microsoft Company, who promotes and extends the already widespread technology of Plug and Play.

For his creation it was supported in pre-existing protocols and technologies as HTTP, XML, SOAP and the protocol UPnP substantially it is the cohesive web between these technologies, with certain extensions where this is essential. It is capable to function above any appliance and platform as it is independent of programming language. It is constituted by various sub systems and the Simple Service Discovery Protocol (SSDP), as the name implies, defines how network services can be discovered on the network.Special feature is through AutoIP, UPnP receive IP addr when DHCP server is absent.Due to usage of multicasting UPnP cannot scale well

\subsection{Salutation [13]}

The Salutation Architecture is designed for home and enterprise environment. The architecture provides a standard method for applications, services and devices to describe and to advertise their capabilities to other applications, services and devices and to find out their capabilities. The Salutation Architecture defines an entity called the Salutation Manager (SLM) that functions as a service broker for applications, services and devices called a Networked Entity. The Salutation Manager allows Networked Entities to discover and utilize the capabilities of other Networked Entities.

\section{E. Bluetooth SDP [9]}

Bluetooth SDP is designed for Bluetooth enabled devices. They address service discovery and do not address service advertising and caching .Service discovery in Bluetooth SDP is of two types as service searching and service browsing. In service searching the user agent sends the type of service along with request and if matched with service provider it sends back the service.In service browsing when client requests the service the list of services offered by service provider is returned back and client selects from it.Bluetooth SDP allows only one hop discovery.

\section{F. Bonjour [14]}

Bonjour is a technology developed by Apple to provide service and device discovery among computers, electronic appliances and other networked devices (e.g. printers, faxes etc.). Bonjour runs over the IP protocol and also has the capability of automatically assigning IP addresses to networked devices, even without the help of a DHCP server. Bonjour's core is a service discovery protocol entirely based on the Multicast DNS Service Discovery - MDNS-SD.

\section{SERVICE DISCOVERY MODES}

There are three service discovery modes.[4]

1. Reactive-This mode is used when service discovery is performed rarely and number of servers are more than client.

2. Proactive-This mode involves global flooding and works well in terms of latency and overhead and number of server is less than number of clients.

3. Hybrid-This mode gives average results and associates a mechanism to find if there is congestion before transmission.

Mode is selected based on actual service context.

\section{SPECIAL FEATURES}

\subsection{Service Description Option}

Services are normally described using UUID[9][15] are used where resources are scarce. They fit well with network layer based service discovery protocol where they increase the width of service message without overhead. Users are not aware of service attributes priority. So they cannot select among similar services.

\subsection{Service selection Mechanism}

After the service requestor receives the reply of service it has to select among available. Service selection is of two types.[16] First is automatic which is based on service ranking system and other is assisted in which service browser is implemented as application. Criteria for selection is route(hop count, bandwidth, delay) and service(server load, energy remaining and capacity)

\subsection{Servie state maintanance techinique}

Service state maintenance technique is important when designing service discovery protocol.. There are two approaches hard state and soft state. In hard state provider must deregister the service before leaving network. In MANET this is unrealistic. In soft state each service record contains TTL and on expiry the record is deleted. Service provider should re-advertise .Above two methods correspond to availability of services and not maintenance of state. Polling and notifications are two methods of state maintenance. In polling the service requestor asks for services as done on demand and in service notification service provider informs client about the change. 


\section{COMPARISION OF VARIOUS TYPES OF SERVICE DISCOVERY PROTOCOLS}

Various service discovery protocols discussed above in this paper are compared taking various criteria as type of network, architecture, storage of service information, search methods Event notification, Service description, Service selection and usage , Fault tolerance and mobility support , Network scalability and Security(Appendix A)

\section{CONCLUSION}

Commercial interest in MANET has recently grown due to the advances in wireless communications. People now except that they should be able to communicate with one another anytime, anywhere, and using any communication device. This is possible by infrastructure-less wireless networks in which nodes can communicate directly to each other without a central coordinator and can relay data to each other in a self-organizing fashion.. Large extend of research has been done in MANET.Mostly low level issues as routing has been dealt a lot but to bring MANET to mass or civilian application the service discovery is important and is an focus of researchers in future.

\section{REFERENCES}

[1] Feng Zhu1 Wei Zhu1 Matt W. Mutka1 Lionel Ni, "Expose or Not? A Progressive Exposure Approach for Service Discovery in Pervasive Computing Environments,"in Proceedings of the 3rd IEEE Int'l Conf. on Pervasive Computing and Communications (PerCom 2005)

[2] Dipanjan Chakraborty, Anupam Joshi, Yelena Yesha, and Tim Finin "Toward Distributed Service Discovery in Pervasive Computing Environments," in IEEE Transactions On Mobile Computing, Vol. 5, No. 2, February 2006.

[3] Xu Shao, Lek Heng Ngoh, Teck Kiong Lee, Teck Yoong Chai, Luying Zhou, Joseph Chee Ming Teo "Multipath CrossLayer Service Discovery" in IEEE Asia-Pacific Services Computing Conference (IEEE APSCC),2009.
[4] Christopher N. Ververidis and George C. Polyzos "Service Discovery for Mobile Ad Hoc Networks: A Survey of Issues and Techniques"in Communications Surveys \& Tutorials, IEEE Issue:3, 16 September 2008

[5] Diego Doval and Donal O'Mahony "Nom: Resource Location and Discovery for AdHoc Mobile Networks"in http://en.scientificcommons.org, 2002.

[6] Uday Mohan, Kevin C. Almeroth and Elizabeth M.BeldingRoyer " Scalable Service Discovery in Mobile Ad Hoc Networks " in Lecture Notes in Computer Science,Springer link, 2004, Volume 3042/2004, 137-149.

[7] R. Nicole, J. Antonio Garcia-Macias, Dante Arias Torres, "Service Discovery in Mobile Ad-Hoc Networks: Better at the Network Layer?" Parallel Processing, 2005. ICPP 2005 Workshops. International Conference Workshops on June 2005.

[8] Choonhwa Lee and Sumi Helal "Protocols For Service Discovery In Dynamic And Mobile Networks" international Journal of Computer Research ISSN 1535-6698 Volume 11, Number 1, pp. 1-12 2002.

[9] "Specification of Bluetooth system"Available :http:www.bluetooth.com.

[10] Sumi Helal, Nitin Desai, Varun Verma and Choonhwa Lee "Konark - A Service Discovery and Delivery Protocol for AdHoc Networks" in Wireless Communications and Networking, 2003. WCNC 2003.

\section{[11] http://www.jini.org/wiki/Lookup}

[12] http://www.upnp.org/

[13] Http://www.salutation.org

[14] Apple Inc "Bonjour Technology White paper"

[15] PAAL E. ENGELSTAD, YAN ZHENG, RAJEEV KOODLI, CHARLES E. PERKINS "Service Discovery Architectures for On-Demand Ad Hoc Networks" in Ad Hoc \& Sensor Wireless Networks, Vol. 1, 2006

[16] Michel Barbeau" Service Discovery Protocols for Ad Hoc Networking" in CASCON 2000 Workshop on ad hoc communications 2000 . 
APPENDIX-A

\begin{tabular}{|c|c|c|c|c|c|}
\hline & $\begin{array}{l}\text { Type of } \\
\text { network }\end{array}$ & Architecture & $\begin{array}{l}\text { Storage of } \\
\text { service } \\
\text { information }\end{array}$ & $\begin{array}{l}\text { Search } \\
\text { methods }\end{array}$ & Event notification \\
\hline SLP [13] & $\begin{array}{l}\text { Enterprise } \\
\text { network }\end{array}$ & $\begin{array}{l}\text { 1. Centralized } \\
\text { (with DA) } \\
\text { 2. P2P(without } \\
\text { DA) } \\
{ }^{\star} \text { DA = Directory } \\
\text { Agent }\end{array}$ & $\begin{array}{c}\text { 1. On DA } \\
\text { 2. On UA } \\
\text { and SA } \\
{ }^{*} U A=\text { User } \\
\text { Agent } \\
\text { SA = Service } \\
\text { Agent }\end{array}$ & $\begin{array}{l}\text { 1. both } \\
\text { active and } \\
\text { passive } \\
\text { discovery } \\
2 \text {. active } \\
\text { discovery } \\
\text { of services }\end{array}$ & - \\
\hline Jini [19] & $\begin{array}{c}\text { Enterprise } \\
\text { network }\end{array}$ & Centralized & $\begin{array}{l}\text { On Lookup } \\
\text { Service }\end{array}$ & $\begin{array}{l}\text { Both active } \\
\text { and passive } \\
\text { discovery } \\
\text { for finding } \\
\text { the Lookup } \\
\text { Service }\end{array}$ & $\begin{array}{l}\text { Distributed } \\
\text { events }\end{array}$ \\
\hline $\begin{array}{l}\text { UPnP } \\
\text { [11] }\end{array}$ & $\begin{array}{c}\text { Enterprise } \\
\text { network }\end{array}$ & P2P & $\begin{array}{c}\text { On every } \\
\text { control point }\end{array}$ & $\begin{array}{l}\text { Both active } \\
\text { and passive } \\
\text { discovery } \\
\text { for finding } \\
\text { services }\end{array}$ & $\begin{array}{c}\text { Eventing } \\
\text { mechanism }\end{array}$ \\
\hline $\begin{array}{c}\text { Salutation } \\
\text { [10] }\end{array}$ & Any network & $\begin{array}{l}\text { Flexible (can } \\
\text { be P2P or } \\
\text { centralized) }\end{array}$ & $\begin{array}{l}\text { Service } \\
\text { Registry } \\
\text { on every } \\
\text { Salutation } \\
\text { Manager }\end{array}$ & $\begin{array}{l}\text { Salutation } \\
\text { Manager } \\
\text { Protocol } \\
\text { between two } \\
\text { SLMs }\end{array}$ & $\begin{array}{l}\text { Long-term } \\
\text { requests }\end{array}$ \\
\hline $\begin{array}{l}\text { Bluetooth } \\
\text { SDP [9] }\end{array}$ & $\begin{array}{c}\text { Small, } \\
\text { maximum } \\
8 \\
\text { devices that } \\
\text { can be } \\
\text { lowcost } \\
\text { and } \\
\text { low-power }\end{array}$ & $\begin{array}{l}\text { Client- } \\
\text { Server }\end{array}$ & $\begin{array}{c}\text { On every } \\
\text { server }\end{array}$ & $\begin{array}{l}\text { Request / } \\
\text { Response } \\
\text { messages } \\
\text { between } \\
\text { client } \\
\text { and server }\end{array}$ & - \\
\hline
\end{tabular}




\begin{tabular}{|c|c|c|c|c|c|}
\hline $\begin{array}{c}\text { Event } \\
\text { notific } \\
\text { ation }\end{array}$ & $\begin{array}{c}\text { Service } \\
\text { description }\end{array}$ & $\begin{array}{l}\text { Service } \\
\text { selecti } \\
\text { on } \\
\text { and } \\
\text { usage }\end{array}$ & $\begin{array}{c}\text { Fault tolerance } \\
\text { and } \\
\text { mobility } \\
\text { support }\end{array}$ & $\begin{array}{l}\text { Network } \\
\text { scalability }\end{array}$ & Security \\
\hline- & $\begin{array}{c}\text { Service } \\
\text { templates } \\
\text { registered } \\
\text { with IANA }\end{array}$ & - & $\begin{array}{l}\text { - Lifetime for } \\
\text { service } \\
\text { registrations }\end{array}$ & $\begin{array}{c}\text {-More DA } \\
\text {-Scope } \\
\text { mechanis } \\
\text { m } \\
\text { for service } \\
\text { grouping }\end{array}$ & $\begin{array}{c}\text { Optional } \\
\text { authentication } \\
\text { of DA } \\
\text { and SA (using } \\
\text { digital } \\
\text { signatures) }\end{array}$ \\
\hline $\begin{array}{l}\text { Distrib } \\
\text { uted } \\
\text { events }\end{array}$ & $\begin{array}{c}\text { Java proxy } \\
\text { objects }\end{array}$ & $\begin{array}{c}\text { Usage } \\
- \\
\text { Java } \\
\text { RMI } \\
\text { via } \\
\text { proxy } \\
\text { objects }\end{array}$ & $\begin{array}{c}\text { Lease } \\
\text { mechanism } \\
\text { for } \\
\text { granting } \\
\text { access to } \\
\text { services }\end{array}$ & $\begin{array}{c}\text {-Service } \\
\text { grouping } \\
\text {-The use } \\
\text { of } \\
\text { federation }\end{array}$ & $\begin{array}{c}\text { - } \\
\text { Authentication } \\
\text { Authorization } \\
\text { (access control } \\
\text { lists) } \\
- \\
\text { Confidentiality } \\
\text {-Integrity }\end{array}$ \\
\hline $\begin{array}{l}\text { Eventi } \\
\text { ng } \\
\text { mecha } \\
\text { nism }\end{array}$ & $\begin{array}{c}\text { XML } \\
\text { description, } \\
\text { based on } \\
\text { UPnP } \\
\text { template } \\
\text { language }\end{array}$ & $\begin{array}{c}\text { Usage } \\
- \\
\text { messa } \\
\text { ges } \\
\text { encaps } \\
\text { ulated }\end{array}$ & $\begin{array}{c}\text {-Expiry time } \\
\text { for } \\
\text { advertisements } \\
\text {-"Device } \\
\text { unavailable" } \\
\text { notification }\end{array}$ & - & - \\
\hline $\begin{array}{l}\text { Long- } \\
\text { term } \\
\text { reques } \\
\text { ts }\end{array}$ & $\begin{array}{l}\text { Service } \\
\text { description } \\
\text { records }\end{array}$ & $\begin{array}{c}\text { Usage } \\
- \\
\text { throug } \\
h \\
\text { RPC }\end{array}$ & $\begin{array}{c}\text { Periodic } \\
\text { availability } \\
\text { check of } \\
\text { services }\end{array}$ & - & $\begin{array}{c}\text { User } \\
\text { authentication } \\
\text { (username } \\
\text { and password) }\end{array}$ \\
\hline- & $\begin{array}{c}\text { Service } \\
\text { attributes } \\
\text { (ID } \\
\text { and value) }\end{array}$ & - & $\begin{array}{l}\text { Implicit (no } \\
\text { caches are } \\
\text { maintained) }\end{array}$ & - & $\begin{array}{l}\text { Determined } \\
\text { in the } \\
\text { Bluetooth } \\
\text { connection } \\
\text { negotiation } \\
\text { phase }\end{array}$ \\
\hline
\end{tabular}

